\title{
Activity of the enzyme adenosine deaminase in serum, erythrocytes and lymphocytes of rats infected with Trypanosoma evansi-ERRATUM
}

Aleksandro S. Da Silva, Luziane P. Belle, Paula E. R. Bitencourt, Viviane C. G. Souza et al. doi:10.1017/ S003118201000123X, Published by Cambridge University Press, 1 September 2010.

It is regretted that the Y-axes in Fig. 4a-d were incorrectly labelled. The word 'erythrocytes' on all four Y-axes should be replaced by 'lymphocytes'. The correct Fig. 4 is shown below.
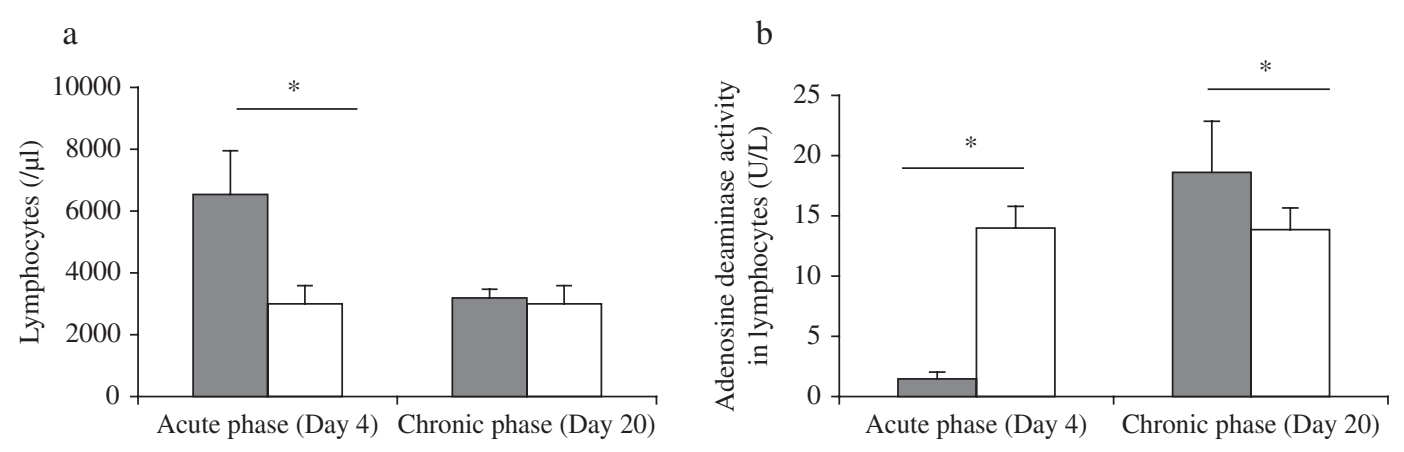

c

d
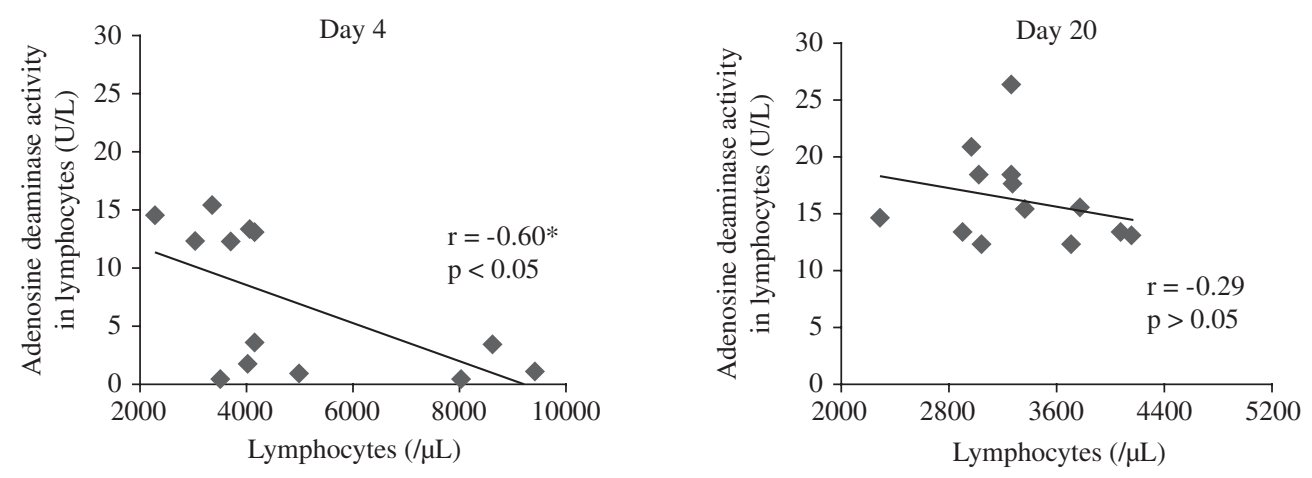

Infected group

Not-infected group

\section{REFERENCE}

Aleksandro S. Da Silva et al. (2010). Activity of the enzyme adenosine deaminase in serum, erythrocytes and lymphocytes of rats infected with Trypanosoma evansi. Parasitology Published by Cambridge University Press, 1 September 2010. doi: 10.1017/S003118201000123X. 